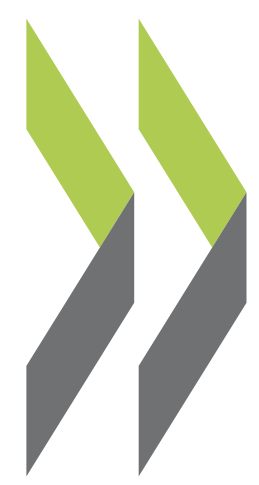

OECD Science, Technology and Industry Working Papers $2017 / 06$

\title{
Frascati Manual R\&D and the System of National Accounts
}

\section{Daniel Ker,}

Fernando Galindo-Rueda 


\section{OECD SCIENCE, TECHNOLOGY, AND INDUSTRY WORKING PAPERS}

The release of this working paper has been authorised by Andrew Wyckoff, OECD Director for Science, Technology, and Innovation and by Martine Durand, OECD Director for Statistics.

Note to Delegations: this document is also available on OLIS under the reference code DSTI/STP/NESTI(2017)9/FINAL

OECD Working Papers should not be reported as representing the official views of the OECD or of its member countries. The opinions expressed and arguments employed are those of the authors.

Working Papers describe preliminary results or research in progress by the author(s) and are published to stimulate discussion on a broad range of issues on which the OECD works. Comments on Working Papers are welcomed, and may be sent to OECD Directorate for Science, Technology and Innovation, OECD, 2 rue André-Pascal, 75775 Paris Cedex 16, France; e-mail: sti.contact@oecd.org.

This document, as well as any data and map included herein, are without prejudice to the status of or sovereignty over any territory, to the delimitation of international frontiers and boundaries and to the name of any territory, city or area.

The statistical data for Israel are supplied by and under the responsibility of the relevant Israeli authorities. The use of such data by the OECD is without prejudice to the status of the Golan Heights, East Jerusalem and Israeli settlements in the West Bank under the terms of international law.

(C) OECD 2017

You can copy, download or print OECD content for your own use, and you can include excerpts from OECD publications, databases and multimedia products in your own documents, presentations, blogs, websites and teaching materials, provided that suitable acknowledgment of OECD as source and copyright owner is given. All requests for commercial use and translation rights should be submitted to rights@oecd.org. 
FRASCATI MANUAL R\&D AND THE SYSTEM OF NATIONAL ACCOUNTS

\author{
Daniel Ker and Fernando Galindo-Rueda
}

OECD Directorate for Science, Technology, and Innovation (STI), Economic Analysis and Statistics Division (EAS)

\begin{abstract}
This working paper looks at the Frascati Manual (FM) framework for Research and Development (R\&D) statistics and the System of National Accounts (SNA) framework of comprehensive economic accounts giving an overview of their shared history and analysing similarities and differences in their approaches to measuring $R \& D$ following a fundamental change of the treatment of $R \& D$ in the 2008 SNA. The working paper also highlights the various actions taken in the 2015 revision of the FM which respond to National Accounts data needs and thereby aims to provide a common platform for collaboration and dialogue between FM and SNA practitioners. Finally, the FM and SNA R\&D statistics are presented and their conceptual, data, and coverage underpinnings compared, helping to elucidate issues that need to be communicated to users so that they can better understand and interpret these related but different R\&D statistics.
\end{abstract}

Acknowledgements: The authors thank country delegates of the Working Party of National Experts on Science and Technology Indicators (NESTI) - in particular John Jankowski, United States National Science Foundation and his colleagues - as well as Nadim Ahmad and Jennifer Ribarsky of the OECD Statistics Directorate and Henk Nijmeijer, Eurostat for their comments and help in producing this working paper. Any errors or omissions are the responsibility of the authors. 


\section{TABLE OF CONTENTS}

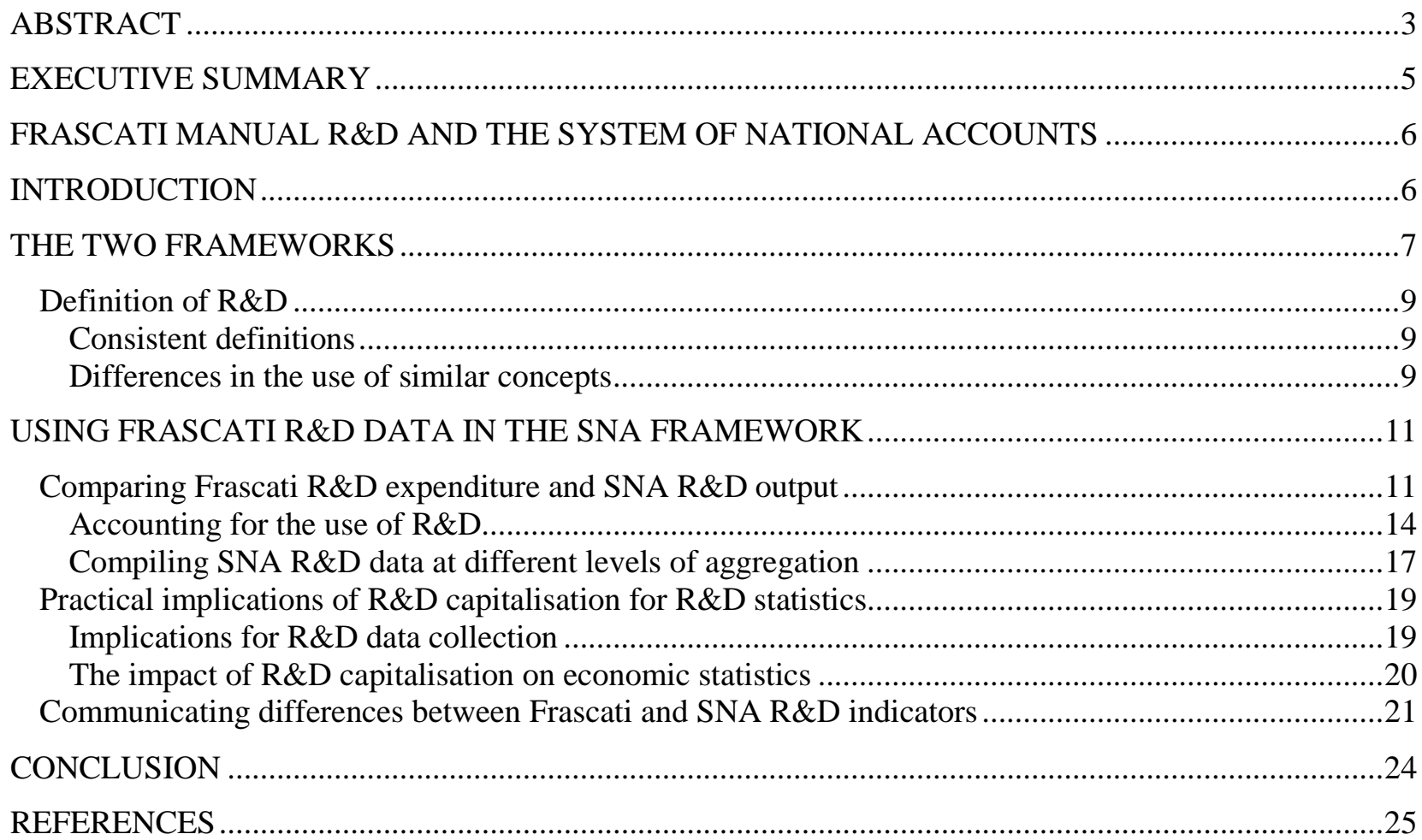




\section{EXECUTIVE SUMMARY}

This working paper complements the Frascati Manual 2015 by focussing on its links and contrasts with the key statistical framework for comprehensive economic accounts - the System of National Accounts ("SNA"; EC et al., 2009). This paper summarises how both frameworks have developed together over time and share many common features and approaches. It goes on to examine how a change incorporated in the 2008 SNA that recognised expenditures on R\&D as investment in R\&D assets led to the use of Frascati Manual-based R\&D series as source data, and the challenges faced due to differences between the two frameworks.

Furthermore, this working paper highlights various responses to these challenges which have been adopted in the 2015 Frascati Manual; these provide new insights and enhanced understanding of the way R\&D is funded and performed, which could help to improve the estimates of R\&D output and investment in National Accounts.

Finally, this working paper examines key aggregates emerging from the two frameworks and elucidates important differences which should be understood when interpreting them.

Key points are:

- National Accounts are now an important channel for the dissemination of R\&D statistics

- The Frascati Manual 2015 adopted a range of changes which can facilitate the production and improvement of National Accounts estimates relating to R\&D, these include:

- More detailed cost-type breakdowns for R\&D expenditure - which allows the application of more appropriate deflators and other parameters in National Accounts compilation methods

- $\quad$ R\&D funding streams disaggregated into those to be requited with a flow of R\&D provided to the funder (i.e. "exchange funds" relating to the sale and purchase of R\&D) and unrequited flows (i.e. "transfer funds" such as grants and donations) - this information promises new insights into the market for R\&D and can help to identify the eventual owners of R\&D assets

- Recommending the separate identification of expenditures relating to R\&D conducted in the course of developing software - so that a key difference between the FM and SNA frameworks (namely the exclusion of these R\&D expenditures from the SNA definition of R\&D investment) can be accurately applied and its impacts understood

- $\quad$ R\&D expenditure aggregates are different from (though related to) R\&D capital formation (investment) aggregates - their similarities and differences must be understood and communicated to facilitate appropriate interpretation

- Those compiling R\&D statistics need to work together with National Accountants to establish implementation priorities and to feed through the impact of changes in R\&D surveys to SNA aggregates 


\section{FRASCATI MANUAL R\&D AND THE SYSTEM OF NATIONAL ACCOUNTS}

\section{INTRODUCTION}

This document complements the 2015 Frascati Manual (OECD, 2015) or “FM 2015” by providing an overview of the manual's evolving links with the System of National Accounts (SNA) statistical framework and how the FM framework contributes to meeting SNA needs following the 2008 SNA recommendation recognising $\mathrm{R} \& \mathrm{D}$ as capital investment (EC et al., 2009) - also known as $R \& D$ capitalisation. It highlights their related history, similarities, and differences, and explains changes in the National Accounts treatment of Research and Experimental Development (R\&D) which have made national accountants key users of Frascati R\&D data, as well as producers of certain statistics relating to R\&D. Furthermore, it draws attention to those changes in FM 2015 which are of most relevance to compilers of National Accounts.

The evolution of the statistical frameworks described in this document has led the OECD to produce various items of complementary guidance over time. This document draws principally on the annex to the previous edition of the Frascati Manual (OECD, 2002), which compared the two frameworks and pointed to the use of SNA satellite accounts on R\&D, and the OECD Handbook on Deriving Capital Measures of Intellectual Property Products (OECD, 2010) - henceforth the "IPP Handbook", which provided the first general set of guidelines on how to use Frascati and related sources to implement the capitalisation of R\&D.

This document represents the next step in that process as it demonstrates the actions taken in the FM 2015 to meet the additional data requirements laid out in the IPP Handbook in order to facilitate R\&D capitalisation. The focus is therefore on highlighting those aspects which are helpful to enable collaboration and mutual understanding between the Frascati and SNA practitioner communities and to present the information in an approachable way and understandable to those without prior knowledge of the 'other' framework. Insofar as the processes of implementing SNA and Frascati are ongoing at the time of completing this document, it should be viewed as a dynamic text which will be updated appropriately following relevant developments in R\&D or National Accounts data, rather than as a static piece of guidance. 


\section{THE TWO FRAMEWORKS}

The Frascati Manual, first published in 1963, has its direct roots in work undertaken in the formative years of the SNA, which was first published in $1953 .{ }^{1}$ The two have grown together over successive editions - with the Frascati Manual drawing certain approaches, definitions, and terminology from the SNA, while Frascati Manual data provided a vital basis for the eventual decision to treat R\&D as investment in the 2008 SNA. Building on efforts in previous revisions, the FM 2015 introduces changes aimed at further alignment with the SNA framework and makes a number of recommendations intended to help national accountants as users of Frascati R\&D data. However, the Frascati Manual was never conceived of as part of the SNA and remains distinct from it, being primarily aimed towards producing a range of data and indicators for use in R\&D and innovation policy-making.

While the SNA is produced jointly by the European Commission (Eurostat), the International Monetary Fund, the OECD, the United Nations, and the World Bank, the Frascati Manual is published by the OECD under the aegis of the OECD Working Party of National Experts on Science and Technology Indicators (NESTI), a working party of the OECD Committee for Scientific and Technological Policy. ${ }^{2}$ As an OECD statistical manual, approval responsibility is shared with the OECD Committee for Statistics and Statistical Policy, whose constituents also have a role in approving revised editions of the SNA.

The convergence between SNA and FM frameworks has accelerated as a result of a change in the 2008 SNA regarding its treatment of R\&D-related "economic activities" and the prevalence of good quality, usable data on R\&D input costs, based on Frascati Manual sources. ${ }^{3}$ In the case of R\&D produced and sold on the markets, the 2008 SNA stipulates that the acquisition of R\&D services by a firm should no longer be treated simply as an in-year cost ("intermediate consumption") from the buyer's perspective but instead, in most cases ${ }^{4}$, as an acquisition of an R\&D asset. This means that domestic sales of R\&D output are no longer offset by equal intermediate consumption (on the part of the purchaser) in the calculation of Gross Domestic Product (GDP) - causing this, as well as the capital stock, to increase. National Accounts data on sales and purchases of R\&D would typically suffice to make this adjustment.

In addition to this, R\&D Capitalisation also has much wider implications because a substantial portion of R\&D is known to be conducted within firms ("market producers") for their own internal use - without external transactions other than those to secure the resources needed to undertake the R\&D activity. In the case of such "own-account R\&D", the cost of these resources was captured in the 1993 SNA - as intermediate consumption and compensation of employees - but the resulting R\&D output was not. The 2008 SNA also recognises that these internal costs, where they are associated with the production of an R\&D asset should now be included as generating output of and amounting to investment in R\&D. This own-account R\&D output, the imputed value of which is designed to approximate the price it would have gained if it had been sold on the market (therefore also including a "mark-up" to proxy "operating surplus" generated above the costs of production), thus also increases GDP and measures of capital stock.

The situation differs for own-account production and purchases of R\&D by Government and other “non-market” producers - including most Higher Education Institutions, which comprise the institutional sector with the second-greatest R\&D expenditures in the FM framework (after business enterprises) but are not a separate sector in the SNA. Under the 1993 SNA, these units' R\&D costs were, indirectly, included as their output is largely valued using a "sum-of-costs" approach. Capitalisation simply changed the treatment of this output from being consumed as final demand to investment in R\&D assets. As a result, the capitalisation of R\&D in these sectors has a limited impact ${ }^{5}$ on GDP - the main impact is an increase in the stock of capital held by these sectors. 
The existence of Frascati $R \& D$ data on $R \& D$ input costs was therefore an important factor behind the decision to "capitalise" R\&D in the 2008 SNA; that is, to treat most spending on purchasing or performing $\mathrm{R} \& \mathrm{D}$ as an investment in $\mathrm{R} \& \mathrm{D}$ assets.

The convergence of the two frameworks is also facilitated by numerous similarities existing between them. For example, the foundation of both is the identification of the statistical units to be covered and the grouping of these into sectors based on their characteristics; Box 1 outlines the improved alignment between FM and SNA sectors. This is no coincidence; the FM approach was inspired by the SNA and the necessity to relate its statistics into mainstream indicators of economic activity.

Having identified the institutional units of interest, both the FM and SNA frameworks then seek to record transactions between them and to understand the activities they engage in. There is, however, a significant difference in the scope and approach taken. The FM is explicitly an input framework, it seeks to capture the cost, source, and nature of inputs (financial and personnel) dedicated to R\&D activities only. By comparison, the SNA production accounts can be viewed in this context as an input-output framework: across a wide range of "economic activities" - including agriculture, manufacturing, services, public administration, etc. - and seeks to capture financial flows (whether actual or imputed) relating to the inputs used in production, outputs generated, and the use of such outputs. Key economic variables including GDP are derived in the SNA framework as balancing items in accounts that compare resources to uses at different levels. ${ }^{6}$

\section{Box 1. Statistical units and sector classifications in the FM and SNA frameworks}

FM 2015 (Ch. 3, section 3.2) adopts the "institutional unit" as the primary unit for statistical compilation and analysis. This aligns FM data with other economic statistics (notably National Accounts), and improves international comparability. The principle of "residence" of an institutional unit in the economy of interest, as applied in the SNA, is also adopted in FM 2015. If a unit is not resident in the domestic economy it is part of the Rest of the World (formerly "abroad") sector and therefore excluded from domestic statistics - as is the case, for example, for International Organisations.

Both frameworks then group institutional units into sectors based on their characteristics - namely whether a unit is subject to government control (and hence public) or not, and whether it charges "economically significant prices" for the things it produces (and hence is a market producer), or not. In certain cases where the more complex SNA classification criteria are too difficult to apply in practice (e.g. where the necessary information are not available from business registers), the main source of funding is used as a potential proxy indication of control (FM 2015, 3.37).

FM 2015 (table 3.1, figure 3.1) outlines the considerable correspondence between FM and SNA institutional sectors. The key difference is that FM R\&D statistics group Higher Education Institutions (HEIs) into a separate institutional sector - reflecting their importance in national R\&D systems and policy making. HEls are variously recorded as non-financial corporations, government units, or Non-Profit Institutions Serving Households (NPISHs) in the SNA framework (depending on the aforementioned characteristics). Units classified in the FM Private Non-Profit (PNP) sector would also be classified in the SNA NPISH sector.

In order to ensure compatibility with other statistical frameworks, FM 2015 makes the specific recommendation that both Frascati and SNA sectors should be available in R\&D datasets (3.48), and thus that it should be clear whether each business enterprise and $\mathrm{HEI}$ is public or private; this is crucial for the integration of R\&D data in National Accounts. It is also recommended that central business/unit registers are used where available (FM 2015, 3.33). 


\section{Definition of R\&D}

\section{Consistent definitions}

Research and experimental development $(R \& D)$ comprise creative and systematic work undertaken in order to increase the stock of knowledge -including knowledge of humankind, culture and societyand to devise new applications of available knowledge. (FM 2015, 2.5)

This definition from the 2015 FM is aligned with the definition in the FM 2002, which the SNA adapted to frame $\mathrm{R} \& \mathrm{D}$ as a productive activity:

Research and development is creative work undertaken on a systematic basis to increase the stock of knowledge, and use this stock of knowledge for the purpose of discovering or developing new products, including improved versions or qualities of existing products, or discovering or developing new or more efficient processes of production (SNA 2008, 6.207).

Although worded slightly differently, this definition is treated as congruent with the FM 2015 definition (and the wording in previous editions of the FM).

While the FM 2015 made only minor changes to the definition of R\&D, it also explicitly introduced five core 'criteria for identifying R\&D'. For an activity to be classified as R\&D it must, at least in principle, jointly be:

- novel: aimed at new knowledge (e.g. findings, evidence)

- creative: focussed on original, not obvious, concepts and hypotheses

- uncertain: the final outcome and/or the effort required are unknown

- systematic: planned and budgeted for

- transferable and/or reproducible: results can be reproduced and/or used ${ }^{7}$

Adoption of these core explanatory criteria will help compilers of R\&D statistics and survey respondents to consistently delineate $R \& D$ and non-R\&D activities, boosting the international comparability of R\&D statistics.

\section{Differences in the use of similar concepts}

$R \& D$ as an activity and as an asset

The Frascati Manual is particularly clear in defining R\&D as an activity, and articulates its methodological guidance accordingly by focusing primarily on capturing the resources dedicated to such activity. In National Accounts, the term "R\&D" may be used to refer not only to R\&D as an activity, i.e. the conducting of R\&D, as described in the above Frascati and SNA definitions, but also to refer to the assets (i.e. "items" of knowledge) resulting from the R\&D activity, e.g. knowledge, resulting from R\&D as evidenced by the existence of intellectual property rights. Such a concept meets the SNA definition of an asset in the sense that it has an owner and can be used over multiple periods (e.g. to produce products based upon it). Because these R\&D assets can themselves be the object of further transactions (e.g. outright sales, licensing), accumulation, and obsolescence, the SNA conceptual scope for R\&D extends the Frascati measurement of R\&D activities (new R\&D) to include, as investment, transfers of existing R\&D assets (e.g. the outright sale of a patent protecting the results of R\&D conducted in previous periods) and the acquisition of services from existing $R \& D$ assets through licensing arrangements ${ }^{8}$. 
Because $R \& D$ performers are not the only actors in the economy engaging in transactions on $R \& D$ assets, FM-based R\&D surveys represent only a partial means for collecting information that is relevant for SNA and research policy perspectives. To date, a number of countries have used their R\&D surveys to secure related information on the exploitation of R\&D outputs as well as on related transactions, thus providing an indication of the main challenges of collecting such data. This has shown that such information can be highly confidential because of its strategic importance to knowledge intensive firms. Such practical experience provides a basis upon which NESTI could develop complementary guidance for use within R\&D surveys or other instruments.

\section{$R \& D$ and software development}

FM 2015, section 2.7 identifies boundaries between R\&D and other activities. In particular, paragraphs 2.68-2.74 address the fact that R\&D and software development can be closely intertwined. Software development may in some cases involve activities that qualify as R\&D, while the pursuit of R\&D projects may sometimes involve the development of new software and the input of software professionals. Software and R\&D activities feed into each other, in the same way that machines are used to produce other machines.

The SNA manages such complex interactions with simplifying rules. The overarching principle is to avoid double counting so that expenditures are recorded as relating to R\&D or software development, not both, when the R\&D is an intrinsic and insoluble part of the software within which it is subsequently embodied. In principle, estimates of the R\&D undertaken in the course of developing software could be shown separately. The IPP handbook recommended that such R\&D costs should be recorded under the category of software assets on the grounds that relevant subsequent transactions, such as those related to the use of the software, would reflect the market price of the software (which in theory would include the value of the embodied R\&D costs). This approach avoids overestimation of GDP and other key National Accounts aggregates but has two important implications:

1 The first concerns the wedge this approach creates between National Accounts R\&D output, investment, etc. and FM Gross Expenditure on R\&D (GERD) statistics, whereby National Accounts $R \& D$ aggregates only provide a partial view of the outputs arising from $R \& D$ when compared to the FM definition.

2 The second concerns the potential impact this has on driving data improvements. The inclusion of $R \& D$ expenditures relating to software development within software investment rather than separately may discourage efforts to collect more detailed data on R\&D expenditures related to software development which would allow more accurate adjustments to be made and for better understanding of this important difference between the frameworks.

Given the specific focus on R\&D in the FM, Box 4.1 of FM 2015 recommends collecting separate data on software R\&D. Ideally this should also be broken down by the various types of expenditure to allow straightforward incorporation in National Accounts methods. Response burden (including whether administrative sources might provide this information) and the prevalence of software activity in the economy (or individual industries) must be considered when designing data collections but, where possible, such collections can provide a vital empirical basis for National Accounts adjustments and a means by which to contextualise this important difference between R\&D estimates from the two frameworks. Such an approach can help to provide a more comprehensive view of the role of R\&D in national economies. 


\section{USING FRASCATI R\&D DATA IN THE SNA FRAMEWORK}

\section{Comparing Frascati R\&D expenditure and SNA R\&D output}

As previously noted, R\&D can take place under any of the following conditions: for sale on the market, for own use by a market producer or within Government units and NPISHs. The SNA offers an approach to valuing own-account $R \& D$ output based upon the total production costs relating to $R \& D$ (though not the costs of R\&D undertaken in the course of developing software, which are instead included within software output). Referred to as the "sum-of-costs" approach, it pools estimates of the various costs of production - including the notional costs of using capital inputs such as buildings and machines. For market producers, an imputed "mark-up", reflecting the element of net operating surplus (roughly equivalent to profit) that would be expected in a market sale of the R\&D, is also included. Individual R\&D investments may under or over deliver on the benefits expected initially but on average (over an industry, sector, or whole economy); the result represents a prudent estimate of their true value. $^{9}$

As a considerable portion of R\&D is conducted in-house, FM data on intramural R\&D expenditures of businesses, government units, higher education institutions, and private non-profit units provide an essential starting point for the sum-of-costs estimation of R\&D output.

$R \& D$ costs

Table 1 shows the alignment of Frascati Manual data with SNA variables for the estimation of R\&D output by summing production costs, along with an illustrative example that shows how different categories relate to each other.

FM current costs (labour costs, other current costs - and further breakdowns) broadly align with SNA Intermediate Consumption of inputs used for R\&D and 'Compensation of Employees' working on $\mathrm{R} \& \mathrm{D}$. One exception is that general payroll taxes, which represent a cost to the R\&D performer, are not part of SNA concept "compensation of employees" because they do not result in a payment to workers social insurance contributions are included though. FM labour costs are thus conceptually broader, leading to the larger value presented as an example in Table 1. Nevertheless, this has no impact on the overall comparison between frameworks because such taxes are part of the SNA "Other taxes on production" of R\&D faced by R\&D performers included towards the bottom of the table.

For current costs other than labour, the FM 2015 clarifies that R\&D inputs should be valued at “purchasers' prices”:

$R \& D$ expenditure totals should be collected and reported at purchasers' prices. Purchasers' prices are the amounts paid by the purchasers, excluding the deductible part of value added taxes (VAT) and similar taxes. Purchasers' prices reflect the actual costs to the users. This means that the valuation of current and capital expenditures on goods and services for $R \& D$ is the total price paid by the reporting unit including any taxes on products, which act to increase the price paid, and the price-reducing effect of any subsidies on the products purchased (FM 2015,4.40).

This is intended to be consistent with purchasers' prices as used in the SNA (defined in SNA 2008, 6.64) and as such Frascati R\&D expenditures comprise the amounts paid for the goods and services themselves; including all attendant taxes on the products purchased (except where the purchaser can deduct from their own tax liabilities, as is generally the case for Value Added Tax (VAT)), and any reduction in the cost of the products purchased due to subsidies received. 
Table 1. Alignment of Frascati intramural R\&D expenditure and SNA R\&D output measures

With illustrative example of a R\&D performing/producing unit (or country)

\begin{tabular}{|c|c|c|c|}
\hline Frascati Manual data & $\begin{array}{l}\text { Example } \\
\text { FM }\end{array}$ & $\begin{array}{l}\text { Example } \\
\text { SNA }\end{array}$ & SNA items \\
\hline $\begin{array}{l}\text { Labour costs of internal R\&D personnel } \\
\text { - includes general payroll taxes and nets out } \\
\text { general labour subsidies } \\
\text { - does not net out specific subsidies for R\&D } \\
\text { personnel }\end{array}$ & 50 & 45 & $\begin{array}{l}\text { Compensation of Employees (working on R\&D) (does } \\
\text { not include the impact of payroll taxes) }\end{array}$ \\
\hline $\begin{array}{l}\text { Other current costs: } \\
\text { - external R\&D personnel } \\
\text { - purchases of materials } \\
\text { - purchases of services (includes payment for } \\
\text { R\&D personnel external to the firm; excludes } \\
\text { R\&D carried out by other units) } \\
\text { - other, not elsewhere classified }\end{array}$ & 40 & 50 & $\begin{array}{l}\text { Intermediate consumption of materials and services } \\
\text { inputs to R\&D production } \\
\cdot \text { Also includes R\&D services purchased } \\
\text { (extramural exchange funding paid out }{ }^{1} \text { ) } \\
\text { by units classified in the R\&D industry }\end{array}$ \\
\hline Capital expenditures: & & & Gross Operating Surplus: \\
\hline $\begin{array}{l}\text { Land and buildings: } \\
\cdot \quad \text { Land } \\
\cdot \quad \text { Buildings } \\
\text { Machinery and equipment: } \\
\cdot \quad \text { information and communications } \\
\text { equipment } \\
\cdot \quad \text { transport equipment } \\
\cdot \quad \text { other machinery and equipment } \\
\text { Capitalised computer software } \\
\text { Other intellectual property products }\end{array}$ & $10^{2}$ & 15 & $\begin{array}{l}\text { Consumption of fixed capital used in } \\
\text { producing R\&D } \\
\text { Net operating surplus generated by capital } \\
\text { used in producing R\&D (market producers } \\
\text { only) } \\
\text { For capital types: } \\
\text { Buildings (land is excluded) } \\
\text { Machinery and equipment: } \\
\cdot \quad \text { information and coms. equipment } \\
\cdot \quad \text { transport equipment } \\
\text { - other machinery and equipment } \\
\text { Capitalised computer software } \\
\text { Other intellectual property products }\end{array}$ \\
\hline & & (10) & $\begin{array}{l}\text { "Other" taxes on production" and imports of R\&D } \\
\text { payable minus subsidies receivable for R\&D }\end{array}$ \\
\hline & & (20) & $\begin{array}{l}\text { Minus expenditure on R\&D undertaken in the course } \\
\text { of developing software - to avoid double counting }\end{array}$ \\
\hline Total FM R\&D intramural expenditure & 100 & 80 & R\&D Output by sum of production costs ${ }^{4}$ \\
\hline
\end{tabular}

1. See section "Identifying ownership of R\&D: performer-based information"

2. May be greater or less than Gross Operating Surplus, FM capital expenditures capture all amounts spent on capital inputs used for R\&D and may be volatile due to the infrequent nature of spending on high-value capital inputs (e.g. new buildings)

3. Other than those taxes which are levied on the products produced, such as Value Added Tax. Also does not include taxes on corporate incomes (i.e. corporation tax). Examples include taxes on pollution, payroll taxes, and taxes on the use of capital.

4. If R\&D output sold is to be measured using an alternative source (e.g. general sales survey), the costs relating to its production should in principle be excluded from the sum-of-costs estimate of R\&D output to avoid double-counting. If these costs cannot be isolated an alternative adjustment is necessary.

Although included in the SNA definition of purchasers' prices, the FM definition does not explicitly refer to the inclusion of separately invoiced transport/delivery charges on the basis that, where such costs exist and relate to inputs to R\&D, they would be recorded in 'other current R\&D costs' (as services where the further breakdown between materials and services purchased is collected).

An important difference between the two frameworks is the accounting for capital acquired and used for R\&D. By focusing on measuring transactions, the Frascati Manual simply records the total expenditure on acquiring various types of capital inputs to $R \& D$ as they occur ${ }^{10}$ - also at purchaser's prices. To avoid double counting, depreciation of the capital inputs used for $R \& D$ is not also included in FM R\&D expenditure figures. By contrast, the SNA is concerned with the 'cost' of using the capital for R\&D over each period, and reflects the facts that: 
- capital goods are used in production over multiple accounting periods until they "wear out" or become obsolete; each year of use means the capital has one less period of useful life remaining. This phenomenon, called "consumption of fixed capital" (but often referred to as "depreciation”, as in business accounting) is relevant to capital inputs used for R\&D activities: for example, lab or computer equipment that is one year old is worth less than an otherwise identical brand new item because it has experienced one year of "wear and tear"; meanwhile, perhaps a newer version might also have been released, making the older version worth less.

- by acquiring a capital asset for one activity, funds need to be raised at a cost or diverted from other possible uses that yield an economic return. Thus, for market producers (i.e. business enterprises), the calculation of costs includes an estimate of the "return" foregone by funding the capital goods used in R\&D - reflected as a "net operating surplus" for the owner.

In practice the costs of capital inputs to R\&D are derived from Perpetual Inventory Method (PIM, see OECD, 2009) used to compute capital stocks, which provide the basis for estimates of depreciation (based on a geometric, straight line, hyperbolic, or other depreciation function) and net operating surplus, based on an assumed "rate of return to capital" (or "mark-up"). It should be noted that these depreciation estimates will be different from those in business accounts, which are impacted by accounting and tax rules.

Together, these comprise the "user costs of capital" inputs used in R\&D production and make up the "Gross Operating Surplus" element of the sum-of-costs valuation of R\&D output (for market producers). As non-market producers (government, NPISH) do not act to maximise profits, the SNA therefore adopts the convention that no return to capital is included and so their Gross Operating Surplus is assumed to equal their consumption of fixed capital (depreciation).

FM 2015 increased the detail recommended in breakdowns of "other current costs" and "machinery and equipment", as well as recommending that purchases of "buildings" be recorded separately from those of "land" since the latter is not subject to depreciation in the SNA (except for improvements to land) and so does not feature in the sum-of-costs valuation of $R \& D$ output. It also recognised the potential for Intellectual Property Products other than software to be used as inputs to R\&D. As well as providing general insight, such detail allows the PIM to be implemented more accurately (and thus improves the robustness of R\&D output estimates).

Detailed breakdowns of $R \& D$ expenditure by types of costs help to improve the quality of National Accounts R\&D estimates: granular information on capital types allow more appropriate deflators and parameters to be selected when applying the PIM, while also breaking down "other current costs" can help in improving $R \& D$ output deflators which have a considerable impact on the interpretation of $R \& D$ data. In practice, general GDP deflators have often been used for R\&D expenditures and this simple approach was supported in an annex to the FM 2002. Meanwhile, many countries' National Accounts deflators for $\mathrm{R} \& \mathrm{D}$ are derived by weighting together relative input price indices; more detailed expenditure breakdowns facilitate this.

\section{Taxes and subsidies relating to $R \& D$}

Taxes on goods and services used for R\&D represent a further cost of R\&D performance, while subsidies received act to reduce the cost borne by R\&D performers. Both are an important part of SNA statistics and are relevant to the production of R\&D (i.e. taxes and subsidies on inputs) and the valuation of R\&D as a product/output itself. 
The use, in many countries, of subsidies that are targeted to facilitate the acquisition of R\&D inputs i.e. inputs used for R\&D activity - highlights another conceptual difference in the way that SNA and FM frameworks add up R\&D costs. The SNA treats any subsidies received on inputs used for R\&D or on R\&D performance as reducing the costs of doing $R \& D$; hence they reduce the value of $R \& D$ output estimated by sum-of-costs. ${ }^{11}$ This is consistent with the purchaser's prices perspective outlined.

The Frascati approach is identical in its treatment of general subsidies on inputs; for example, a general subsidy paid on the use of eco-friendly printer paper reduces the purchaser's price and hence the $\mathrm{R} \& \mathrm{D}$ expenditure recorded. However, an alternative treatment is adopted in the case of $R \& D$-specific subsidies such as a subsidy paid for each researcher employed. This is because an equivalent degree of support for R\&D may also be given in alternative ways, such as through reduced corporation tax for R\&D performers, and the choice of one transfer mechanism or another should, as a matter of principle, not result in differing impacts on FM R\&D expenditure measures and indicators. The principle that $R \& D$-specific subsidies (on inputs or paid on the overall R\&D activity) should not be netted off from expenditures on R\&D performance as recorded in FM statistics is established in FM 20154.22 and helps to ensure international comparability of R\&D statistics. As such, FM 2015 adopts an ad-hoc approach when it applies to taxes and subsidies that are specifically targeted towards $R \& D$ but for any general taxes and subsidies, the approach is otherwise fully consistent with the SNA. ${ }^{12}$

\section{Accounting for the use of $R \& D$}

\section{Identifying ownership of R\&D: performer-based information}

The SNA, as a resource-use based framework, does not stop at measuring output. It is also of particular relevance to know how R\&D resources are used in an economy. Since the 2008 SNA, one of those possible uses is the accumulation of R\&D as an asset that can be used in future periods and which may be subject to further transactions and obsolescence. This new treatment facilitates better understanding of the economic role of $R \& D$; for example in influencing the differing economic performance of various industries and countries.

The Frascati Manual provides a number of tools to assist in the analysis of the use of R\&D that has been produced in the domestic economy. One of the most relevant is information on sources of funds for $\mathrm{R} \& \mathrm{D}$; these data record the amount of money received from other units which was actually spent on the performance of R\&D in the reference period. For example, a business' R\&D spending may be funded from their own funds, funds from other businesses, funds from government, funds from abroad, etc. This information provides a useful but very approximate picture of the likely owner of the R\&D output and can support R\&D SNA development and capitalisation efforts, on the assumption that in most cases, the institutional sector that funds the $R \& D$ is the one likely to have the right to use its outcomes. This assumption, however, is blunt and would be considerably less likely to apply where funds are received from government or non-profit organisations. In recognition of this, the FM 2015 introduced additional recommendations aimed at characterising the nature of the arrangements under which $R \& D$ performers receive funds from third parties for $R \& D$ purposes:

- $\quad$ sub-classification of funds received by the unit (where the performer approach is used) from other units for the performance of R\&D into "exchange funds" to be requited by the provision of $R \& D$ services back to the funder and "transfer funds" for which there is no such compensatory flow of R\&D services (FM 2015 4.109).

- $\quad$ information on the value of (i.e. monies received from) "sales of R\&D" in the period (FM 2015 4.130-2). While the Frascati Manual does not make detailed recommendations on how this should be undertaken, it would be beneficial, where possible, to distinguish income from 
sales of R\&D services provided directly to customers and income from royalties, patent sales, etc.

This information serves two major purposes. Firstly, it allows market R\&D output, which national accountants may have fed into their output estimates through other sources, to be identified in order to avoid double counting (i.e. counting market $R \& D$ from sales of $R \& D$ in addition to part of $R \& D$ output estimated on a sum-of-costs basis that corresponds to R\&D for sale). ${ }^{13}$ Secondly, this enables ownership of the R\&D to be attributed to an external funding sector when funds have been received on an exchange basis - in payment for the R\&D output.

The distinction between exchange and transfer based funding from government is of particular policy relevance, as it enables the separate identification of unconditional funding in the form of grants and contributions (transfer) and procurement of services under market conditions (exchange). Some public procurement arrangements may entail a combination of both, for example if government retains the right to use the IP only for its own use but the firm is able to commercialise the knowledge for other customers and applications.

\section{Acquiring $R \& D$ services}

The SNA treats almost all payments for R\&D services ${ }^{14}$ as an acquisition of R\&D assets - which increases the purchasing unit's capital stock. However, an important exception is made when the purchasing unit is in the "Scientific Research and Development" industry. These units specialise in the performance of R\&D and so the purchased $R \& D$ may be used as an input to their own R\&D activities. In the absence of detailed information on the nature of that input (i.e. as a capital input used across multiple periods and $R \& D$ projects or as an intermediate input to a specific $R \& D$ project), national accountants make the simplifying assumption that all such R\&D is incorporated, without transformation, in the R\&D performed by the purchaser (OECD, 2010, section I.4). R\&D purchases by firms in the Scientific R\&D industry are therefore included as an additional "current cost" when valuing their R\&D output by sum-of-costs. This is shown on the right hand side of Table $\mathbf{1}$ and may be measured either through a general purchasers' survey or using FM "exchange funds paid to others" - depending on which provides the most robust estimates.

In addition to using other external services as part of their internal R\&D activity, units that perform $R \& D$ may also need to acquire $R \& D$ services from other units (or acquire rights to use R\&D assets produced in the past). The FM has long recommended the separate collection of amounts paid by $R \& D$ performing units to other units for the performance of R\&D (i.e. payments for extramural $R \& D)$ and also on funding received by R\&D performing units from other units for the conduct of $R \& D$. Because of the risk of both parties reporting the same R\&D expenditures and subsequent double counting, the Frascati Manual excludes payments for R\&D carried out extramurally from the measure of a unit's R\&D expenditure.

In order to better understand these funding flows, FM 2015 advocates identifying not only the funding recipient but also the nature of the transaction (requited "exchange" funds or unrequited "transfer" funds).

Clearly then, the valuation of R\&D output varies based on the industry of the performer. From this it follows that the choice and classification of statistical units used in R\&D data is of increased importance; the move in FM 2015 to standardise at the level of the institutional unit provides a clear and consistent basis for compilation and is aligned with the National Accounts framework. 


\section{Identifying $R \& D$ capital formation}

Having noted the similarities and differences between the intramural R\&D of a unit and its SNA R\&D output equivalent in Table 1, Table 2 goes on to illustrate the differences between the latter and the SNA measure of R\&D Gross fixed capital formation (R\&D GFCF).

As previously noted, $R \& D$ output that is sold to other units does not contribute to the performer's capital formation, instead being capital formation of the purchasing entity (row B). The FM 2015 (4.1302) advocates the collection of information on $R \& D$ sales receipts occurring in the period.

Table 2. Alignment of Frascati intramural R\&D expenditure and SNA R\&D capital formation measures Illustrative example of R\&D performing/producing $\underline{\text { unit }}^{1}$; follows from Table 1

\begin{tabular}{|c|c|c|c|c|}
\hline Frascati Manual data & $\begin{array}{l}\text { Example } \\
\text { FM }\end{array}$ & $\begin{array}{l}\text { Example } \\
\text { SNA }\end{array}$ & SNA items & \\
\hline $\begin{array}{l}\text { Total FM R\&D intramural expenditure } \\
\text { from Table } 1\end{array}$ & 100 & 80 & $\begin{array}{l}\text { R\&D Output by sum of production costs } \\
\text { from Table } 1\end{array}$ & A \\
\hline $\begin{array}{l}\text { R\&D sold: available where "sales of R\&D in the } \\
\text { period" are collected per FM } 20154.130-2\end{array}$ & $(10)$ & $(10)$ & R\&D output sold ${ }^{2}$ & B \\
\hline $\begin{array}{l}\text { Extramural exchange funding of R\&D (where } \\
\text { collected; usually only covers R\&D performers) }\end{array}$ & 15 & 15 & $\begin{array}{l}\text { R\&D services acquired from other units, } \\
\text { including from abroad }\end{array}$ & $\mathbf{C}$ \\
\hline $\begin{array}{l}\text { less extramural exchange funding } \\
\text { paid out by units classified in the } \\
\text { Scientific R\&D industry }\end{array}$ & & & $\begin{array}{l}\text { Except when purchaser is in the } \\
\text { Scientific R\&D industry (treated as } \\
\text { intermediate consumption) }\end{array}$ & \\
\hline & & & $\begin{array}{l}\text { Usually measured using non-FM source (e.g. } \\
\text { general purchases survey) but may be } \\
\text { estimated based upon FM extramural exchange } \\
\text { funding) }\end{array}$ & \\
\hline [Not captured by Frascati data] & & 25 & $\begin{array}{l}\text { Transfers relating to R\&D assets produced in } \\
\text { previous periods (e.g. outright sales of R\&D } \\
\text { assets, licencing of R\&D assets) }\end{array}$ & $\mathbf{D}$ \\
\hline [No directly equivalent FM concept] & & 110 & Gross fixed capital formation of R\&D & $\mathbf{E}$ \\
\hline
\end{tabular}

Frascati sources can also provide information on R\&D obtained from third parties. However, this is limited in two ways as they only tend to cover:

- $\quad$ units that are themselves R\&D performers (row C) - those units without internal R\&D production but which acquire R\&D are not typically covered in R\&D performer surveys;

- the acquisition of $R \& D$ assets corresponding to $R \& D$ carried out in the current period - as payments for extramural R\&D exclude purchases of rights to intellectual property products that came into existence as part of previous R\&D efforts (row D). ${ }^{15}$ Their estimation would require extensions to R\&D and other statistical sources in the fashion proposed in the IPP Handbook (OECD, 2010)

The unit's R\&D capital formation ultimately consists of its own-account R\&D output plus R\&D services or assets purchased (row E). R\&D capital formation series can be accumulated into R\&D stock and capital consumption estimates by applying the PIM (briefly outlined in paragraph 29), with additional information on R\&D asset lives (Box 2). 


\section{Box 2. Measuring R\&D asset lives and transactions on pre-existing R\&D assets}

Information on the length of time over which R\&D assets are used (their "lives") allows survival and depreciation profiles to be computed to keep R\&D assets in the capital stock for an appropriate duration. Although R\&D assets are not subject to the wear-and-tear which afflicts physical capital, the useful life of $R \& D$ is limited because $R \& D$ is generally superseded at some point by further research which renders it obsolete (either instantaneously or gradually so that the old R\&D asset loses its value over time). Common approaches to estimating R\&D service lives are survey questions asking about how long R\&D assets are useful for/provide benefits to their owners and deriving estimates from administrative data on payments of annual patent renewal fees (on the assumption that patents protect the results of R\&D, are only renewed if the $R \& D$ they protect remains of value, and that findings will be representative of R\&D in general). Ker (2014) provides a detailed comparative appraisal of these two approaches.

The survey approach was encouraged by the "Canberra II Expert Group on the Measurement of NonFinancial Assets" (IPP Handbook Ch. 2, section 19) and information on R\&D asset lives was also specifically requested for collection under FM 2015 by OECD and European Union (EU) National Accounts stakeholders. In response to these and related requests, the OECD NESTI established a dedicated revision group on R\&D outputs to assess the feasibility of collecting information on the above and other R\&D output-related items. Throughout the revision of the Frascati Manual, a number of recent experiences on measuring R\&D asset lives were discussed. These highlighted highly consistent survey results. In consultation with national accounts experts, it was ultimately decided not to include specific guidance on how to collect data on this aspect of R\&D and to prioritise elements that required regular data collection on inputs to R\&D for SNA purposes.

Measuring transactions on pre-existing R\&D assets remains a more pressing open area for research and guidance development. Other than data concerning international transactions, this information is not routinely available and for this reason it was specifically requested that methods for collection were considered by NESTI. This request could not be ultimately accommodated within FM 2015 but this continues to be a topic of active discussion within the working party. The elaboration of standard practice on transactions on R\&D and other knowledge-based assets is a target of future work that would require exploring potential data sources (surveys and others), and testing questions under different survey instruments, in collaboration with relevant expert groups.

\section{Compiling SNA R\&D data at different levels of aggregation}

Economy-wide statistics - the role of exports and imports of $R \& D$

The compilation of National Accounts and related R\&D statistics at the level of an economy abstracts from R\&D flows occurring within the economy but accounts for imports of R\&D. That is, cases where R\&D services/assets are produced outside the domestic economy (i.e. in the Rest of the World sector) but are delivered to/owned by units in the domestic economy (imports) or R\&D services/assets produced domestically will be owned by units in the Rest of the World sector (exports).

Imports of R\&D can be estimated from several different sources:

- $\quad$ R\&D will usually be captured as a product within Balance of Payments statistics

- $\quad$ Frascati data on extramural funding for R\&D provided by domestic R\&D performers to units in the Rest of the World can give an indication of the R\&D services imported by domestic R\&D performers.

- furthermore, the disaggregation of these funds into 'exchange' and 'transfer' funds (per FM 2015 4.118) will make it clearer which flows result in imports 
As previously noted, the latter two will only relate to the subset of $R \& D$ imports that are bought by $R \& D$ performers (unless this question is addressed to the wider business population). Nevertheless, it will provide a partial estimate if no other source is available, or provide further useful information that complements other sources (e.g. as a "sense check" on R\&D imports recorded in the Balance of Payments statistics).

Exports of R\&D might also be estimated using R\&D funding by source, with (exchange) funding received from overseas as a proportion of total intramural $R \& D$ spending giving a rough indication of the share of R\&D output that is exported.

It will often be the case that other sources, such as Balance of Payments statistics, offer an estimate of the amount of R\&D products exported. It should be expected that these will differ from Frascati-based estimates due to differences in coverage, methods, valuation principles, timing, definitions, and other factors. Those compiling R\&D statistics will need to identify which source is most appropriate.

FM 2015 also introduced a new chapter on 'Measurement of R\&D Globalisation' (Ch. 11). This lays out a framework for collecting information on cross-border flows of R\&D between affiliated companies within Multi-National Enterprises (MNEs), as well as considering cross-border transactions between unaffiliated businesses and those involving non-business units. Such information would greatly improve understanding of cross-border movements of R\&D and could form an important source of new data within the National Accounts. This includes when constructing Gross National Income (GNI), a concept which adjusts GDP for cross-border income flows. In the SNA, payments for R\&D services or license fees are recorded as payments for services received, however, if no explicit payment is made it is likely to show up as an income flow. This gives GNI attractive features in a globalised and increasingly knowledge-based economy because it is less impacted by business' decisions on where to locate R\&D assets and whether or not to record explicit payments.

\section{Institutional sector and industry-level analysis}

The Frascati Manual advocates compiling estimates not only at the level of the whole economy but also for institutional sectors and industries. This gives valuable insights into the relative size and importance of different parts of the economy in terms of R\&D expenditure and employment; their different focusses - e.g. basic research, applied research, experimental development; fields of R\&D (FORD), and the relationships between them and with the Rest of the World (e.g. funding flows). This is highly relevant and useful information for policy makers.

Sectoral and industry analyses are likewise a key foundation of the SNA. The comprehensive integration of R\&D activities in National Accounts provides a powerful tool for understanding the relations between R\&D and other activities. Beyond this, potential links between the acquisition of R\&D and the relative performance of different sectors and industries is possible - with the potential for a wide range of policy-relevant insights. Such National Accounts R\&D data complement the detailed information available directly from the Frascati Manual and together provide an enhanced basis for setting R\&D policies and assessing their impacts.

The compilation of SNA R\&D output statistics at the institutional sector level is facilitated by the close relationship between Frascati and SNA sectors and recommendations in FM 2015 on the use of common registers and dual tagging. Performer-based R\&D data can provide for most SNA needs while requiring limited assumptions and external sources because FM recommendations on classifications for sources of funds allow for an approximate functional distribution at the institutional sector level. 
The use of business registers recommended in FM 2015 is also relevant to the compilation of R\&D output at the industry level (within or across institutional sectors) since such registers will usually contain relevant information such as standard industrial classification codes. Alternatively, some countries collect the information needed to assign $R \& D$ performers to an industry through their R\&D surveys. The estimation of R\&D output presents relatively little difficulty as long as the main economic activity of the R\&D performer is consistently identified and it is sufficiently coherent with other economic statistics. It should be noted that national practices for associating R\&D expenditure data with industries can vary substantially and detailed breakdowns may be challenging to attain due to sample sizes and disclosure issues. The OECD complements the "raw" data on R\&D gathered on expenditures by main activity (industry) and industry served by producing the Analytical Business Enterprise R\&D (ANBERD) dataset ${ }^{16}$, which includes computations to provide improved industry detail and international comparability.

Estimating R\&D capital formation is more challenging because the nature of the R\&D output must be established (i.e. market output for sale, own-account R\&D, non-market R\&D) and, in the case of market $R \& D$, the purchasing sector or industry must be identified so that the $R \& D$ can be included in the appropriate sector and industry capital formation (investment) and capital stock statistics. As outlined, Frascati sources of funds data (and particularly exchange funds by source) can provide a useful indication of the institutional sector which will own and use the R\&D. Information on R\&D by "industry served" may also be of use.

Another aspect of the measurement of R\&D expenditures, output, and GFCF is the isolation of changes in the volume of $R \& D$ over time from changes in the price of $R \& D$ through the use of deflators. FM 2015 continues to feature an annex - which was originally included in FM 2002 - on "R\&D Deflators and Currency Converters". This annex recommends use of the implicit GDP deflator unless a 'full set' of R\&D deflators is available for all countries. It is intended that the annex will be revised to take account of developments in $R \& D$ deflators, which received considerable attention during the work to capitalise $R \& D$ in National Accounts.

\section{Practical implications of $R \& D$ capitalisation for $R \& D$ statistics}

\section{Implications for R\&D data collection}

The comprehensive revision which ultimately culminated in the FM 2015, has the clear implication that those compiling R\&D statistics should reassess their practices: from the data collection vehicles used (e.g. the balance of administrative and survey data), through the survey questions asked (including the definitions used, breakdowns implemented, etc.), the classification of R\&D performing units and the statistical unit used for compilations, and the final statistics to be presented. National Accounts are now a source of statistics on R\&D output and investment and, as set out in this document, the needs of national accountants as R\&D data users were considered throughout the revision process; with a wide range of the changes made being relevant.

The important final step is for those implementing the FM 2015 to work with national accountants to identify and prioritise those changes that will enable and improve R\&D output, investment, and stock figures. Priority areas may include ensuring R\&D statistics are compiled at the level of the institutional unit (vital in determining the boundary between intramural and extramural R\&D), application of the elaborated FM classification criteria in chapter 3 and cross-classification of units to SNA institutional sectors, isolating R\&D expenditures related to software development, and the breakdown of funding flows into exchange and transfer funds. FM and SNA practitioners are encouraged to engage together in identifying and setting priorities appropriate to their local situation. 


\section{The impact of $R \& D$ capitalisation on economic statistics}

As well as increasing GDP and investment figures, the recognition of R\&D expenditure as creating assets improves sector and national balance sheets, increasing wealth through more assets being recorded. R\&D capitalisation also impacts the income flows which should be recorded in the current account of national balance of payments statistics as a result of R\&D holdings by multinational companies (see Yorgason, 2007). Table 3 outlines the ways in which the changes to the SNA accounting for different types of R\&D impact GDP and other key National Accounts statistics.

Table 3. Impacts of R\&D accounting changes on key National Accounts statistics

\begin{tabular}{|c|c|c|c|}
\hline $\begin{array}{l}\text { Type of } \\
\text { R\&D }\end{array}$ & SNA93 Treatment & SNA 2008 Treatment & Impact on key statistics \\
\hline $\begin{array}{l}\text { Market R\&D } \\
\text { (R\&D } \\
\text { produced and } \\
\text { sold) }\end{array}$ & $\begin{array}{l}\text { Output of the producer } \\
\text { Intermediate consumption of the } \\
\text { purchaser }\end{array}$ & $\begin{array}{l}\text { Output of the producer } \\
\text { Investment of the purchaser } \\
\text { (intermediate consumption if } \\
\text { purchaser is in R\&D industry) }\end{array}$ & $\begin{array}{l}\text { Output unchanged but } \\
\text { intermediate consumption } \\
\text { decreases so GDP increases. }\end{array}$ \\
\hline $\begin{array}{l}\text { Own-account } \\
\text { R\&D by } \\
\text { market } \\
\text { producers }\end{array}$ & $\begin{array}{l}\text { Not measured. } \\
\text { Costs of materials and services } \\
\text { inputs to R\&D included in } \\
\text { intermediate consumption. } \\
\text { Compensation of employees } \\
\text { working on R\&D included in the } \\
\text { income accounts and value } \\
\text { added. }\end{array}$ & $\begin{array}{l}\text { Output and investment of the } \\
\text { producer }\end{array}$ & $\begin{array}{l}\text { Output is increased by the value of } \\
\text { own-account R\&D; intermediate } \\
\text { consumption is unchanged so } \\
\text { GDP increases. }\end{array}$ \\
\hline $\begin{array}{l}\text { Non-market } \\
\text { R\&D output }\end{array}$ & $\begin{array}{l}\text { Costs captured (but not } \\
\text { identified) in sum-of-costs } \\
\text { valuation of non-market output, } \\
\text { fed through to } \\
\text { government/NPISH final } \\
\text { consumption. }\end{array}$ & $\begin{array}{l}\text { Identified and treated as } \\
\text { investment in R\&D assets }\end{array}$ & $\begin{array}{l}\text { All non-market output is measured } \\
\text { by summing production costs. } \\
\text { Under the } 2008 \text { SNA these are } \\
\text { increased by the capital } \\
\text { consumption (depreciation) of the } \\
\text { new R\&D assets so GDP } \\
\text { increases. This also feeds through } \\
\text { to final government/NPISH } \\
\text { investment. } \\
\text { Additional cost of capital } \\
\text { consumption of R\&D will reduce } \\
\text { government current } \\
\text { surplus/increase government } \\
\text { current deficit. }\end{array}$ \\
\hline
\end{tabular}

Note: this table does not present all impacts occurring throughout the entire system of accounts

R\&D statistics are commonly expressed as a proportion of GDP (for sectors and industries, Gross Value Added), a normalising factor to indicate the intensity of R\&D efforts undertaken within an economy (or sector, industry). The resulting increases in GDP outlined above therefore have an impact on key R\&D indicators - notably the ratios of GERD, BERD (Business Expenditure on R\&D), HERD (Higher Education R\&D expenditure), and GOVERD (Government R\&D expenditure) to GDP - see OECD (2014) for a detailed exposition of the impact on the OECD GERD to GDP ratio. 


\section{Communicating differences between Frascati and SNA R\&D indicators}

The National Accounts are a source of new statistics on R\&D output and investment. However, while these figures are Frascati Manual based, they do not present the same concepts or coverage as Frascati R\&D data and indicators. R\&D output is the most closely aligned to Frascati R\&D expenditure but differs in terms of the treatment of capital inputs (expenditure vs "cost" estimated using the PIM), taxes and subsidies, R\&D undertaken in the course of developing software (included as software rather than R\&D within the SNA), and the measurement of some or all market R\&D through alternative sources (e.g. sales/purchases surveys). Gross Fixed Capital Formation (GFCF, also known as "investment") of R\&D assets also includes any imported R\&D and may also include, as negative entries, any sales of existing R\&D. Cross-border transfers of R\&D assets are similarly treated (though in practice few countries have sufficient data to apply this adjustment).

Before the 2008 SNA, GERD was often portrayed as a proxy for R\&D investment in the absence of a better indicator. R\&D GFCF is better aligned with the investment concept though it should be recalled that the SNA excludes from this all R\&D undertaken in the course of software development (see section "R\&D and software development”) - impacting their interpretation ${ }^{17}$. When communicating R\&D statistics (especially when presenting Frascati and National Accounts R\&D figures together) it is vital to ensure clarity about their different conceptual bases, data sources, and coverage so that users can properly understand the information represented by each series.

In terms of numerical outputs, a number of countries' R\&D GFCF and stock estimates are now available in the OECD National Accounts Database (oe.cd/1Fb). Figure 1 presents GERD and R\&D GFCF data, as a proportion of GDP, for the latest period in which both are available at the time of writing. A country's R\&D GFCF consists of R\&D produced domestically, plus imported R\&D, less $R \& D$ exported (less $R \& D$ used as an intermediate input to further $R \& D$ for performers in the $R \& D$ industry, ISIC 72).

It can be seen that, in most cases, GERD is greater than R\&D GFCF, though they are often relatively similar. This is to be expected as countries' R\&D GFCF values are in large part estimated from, and thus closely related to, the components of GERD. Nevertheless, differences between the two can be seen in some cases; GERD is markedly larger than R\&D GFCF in Israel, and Canada, but considerably smaller in Ireland.

In principle, such differences between GERD and R\&D GFCF should primarily be driven by imports and exports of $R \& D$, though the exclusion of $R \& D$ undertaken in the course of developing software may also help to explain why R\&D GFCF seems to be systematically lower than GERD in general. Other factors such as variation in the treatment of costs of capital inputs to $R \& D$ could also cause some differences. 
Figure 1. Comparison of GERD and R\&D GFCF estimates

As a percentage of GDP, latest year in which both figures are available

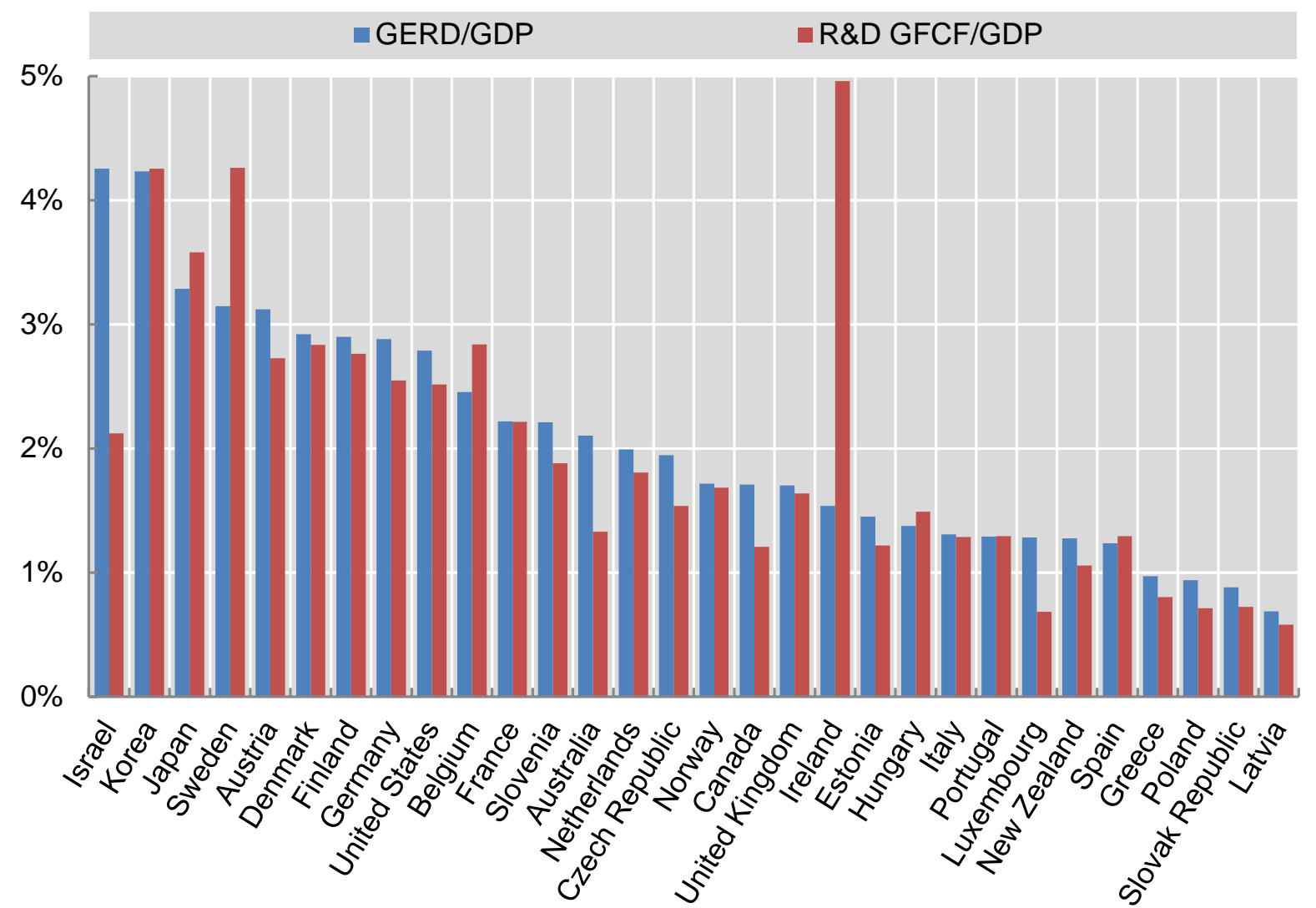

1. 2015: Austria, Belgium, Canada, Czech Republic, Finland, France, Greece, Hungary, Israel, Japan, Korea, Luxembourg, Netherlands, New Zealand, Slovenia, United Kingdom, United States. 2014: Denmark, Estonia, Germany, Ireland, Latvia, Norway, Poland, Portugal, Slovak Republic, Spain, Sweden. 2013: Australia, Italy.

2. US GERD figures exclude most or all expenditure on capital inputs to R\&D - to that extent the numerator will be understated; figures for 2014 (https://www.nsf.gov/statistics/2016/nsf16315/) indicate that the inclusion of business capital expenditure increases total Business Expenditure on R\&D (BERD, the main component of GERD, accounting for around $70 \%$ of the total) by around $4.4 \%$.

3. GERD includes R\&D conducted in the course of developing software, R\&D GFCF does not.

Source: OECD National Accounts Database (oe.cd/1Fb), OECD R\&D Statistics (RDS) database (www.oecd.org/sti/rds), US Bureau of Economic Analysis, fixed assets accounts (http://www.bea.gov/iTable/iTable.cfm?ReqID=10\&step=1\#reqid=10\&step=1\&isuri=1). Retrieved October 2017.

In the case of Ireland, R\&D GFCF is much larger than GERD, at 5.0\% of GDP compared to 1.5\%. This can also be seen in Figure 2 which shows the evolution of R\&D GFCF as a proportion of GERD over time. Ireland's R\&D GFCF has grown much more quickly than GERD over the period. This difference is driven by large imports of R\&D assets (as noted in OECD, 2016) and has led Ireland's R\&D stock (not presented) to increase more than ninefold, from 9.6bn USD PPP in 2000 to 88bn USD PPP in 2014 (latest available). 
Figure 2. Trends in the evolution of R\&D GFCF as a proportion of GERD

$$
1995-2015
$$

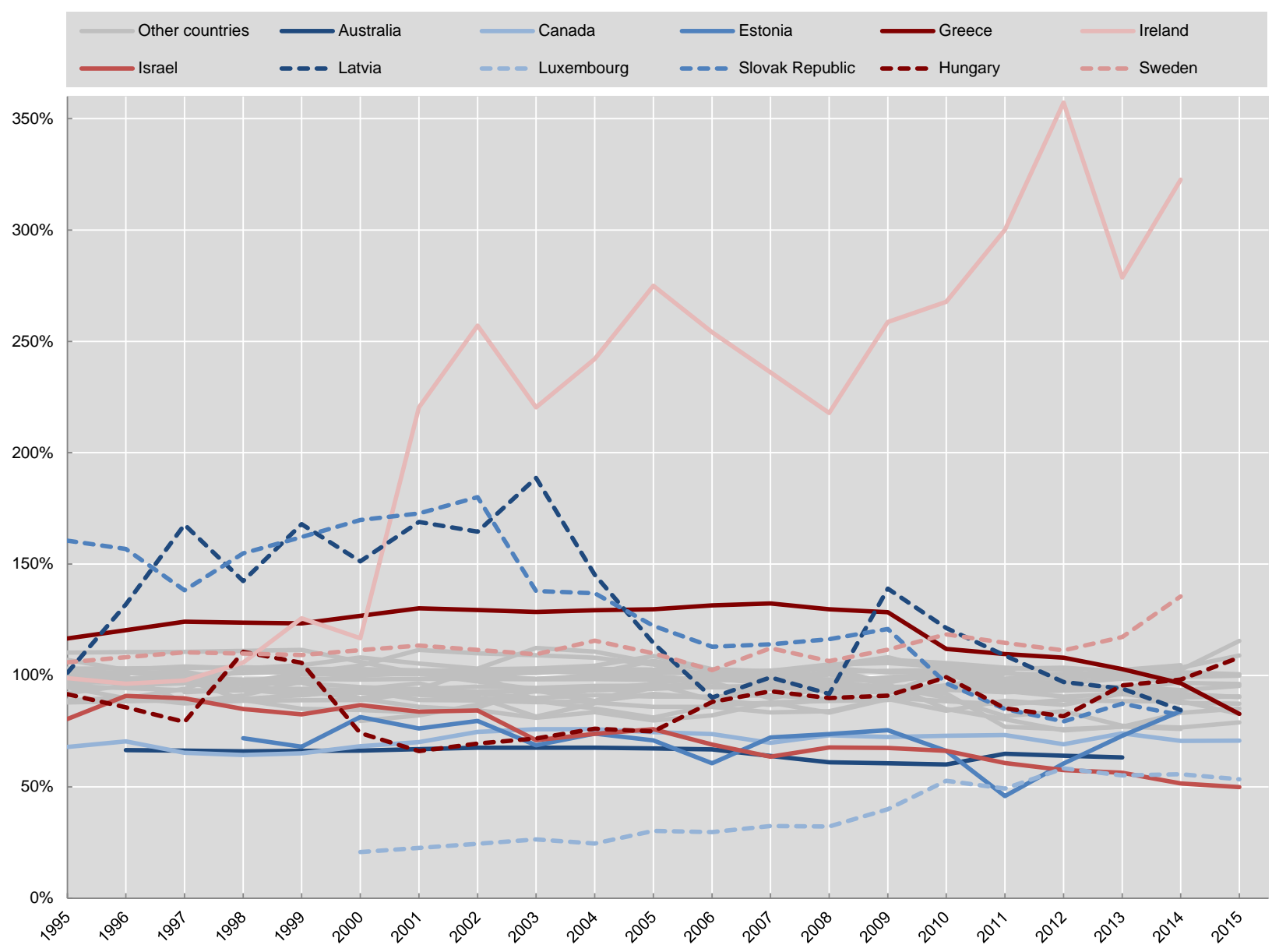

1. "Other countries": Austria, Belgium, Czech Republic, Denmark, Finland, France, Germany, Italy, Japan, Korea, Netherlands, New Zealand, Norway, Poland, Portugal, Slovenia, Spain, United Kingdom, United States.

2. US GERD figures exclude most or all expenditure on capital inputs to R\&D - to that extent the denominator will be understated; figures for 2014 (https://www.nsf.gov/statistics/2016/nsf16315/) indicate that the inclusion of business capital expenditure increases total Business Expenditure on R\&D (BERD, the main component of GERD, accounting for around $70 \%$ of the total) by around $4.4 \%$.

3. GERD includes R\&D conducted in the course of developing software, R\&D GFCF does not.

Source: OECD National Accounts Database (oe.cd/1Fb), OECD R\&D Statistics (RDS) database (www.oecd.org/sti/rds), US Bureau of Economic Analysis, fixed assets accounts (http://www.bea.gov/iTable/iTable.cfm?ReqID=10\&step=1\#reqid=10\&step=1\&isuri=1). Retrieved October 2017.

Most countries' R\&D GFCF/GERD ratios are below 100\%. Furthermore, Figure 2 shows that a majority of countries' R\&D GFCF/GERD ratios have been relatively stable over time - generally falling within a band between roughly 80 and $110 \%$. Nevertheless, a number of countries join Ireland in having strikingly different trends over time. While Ireland appears to be a significant net importer of R\&D, Israel appears likely to be a net exporter of $\mathrm{R} \& \mathrm{D}$ (though the divergence may also be related to $\mathrm{R} \& \mathrm{D}$ undertaken in the course of software development, which is excluded from R\&D GFCF). R\&D GFCF in Israel is less than half of GERD in 2014, having declined from nearer $100 \%$ in the 1990 s. 


\section{CONCLUSION}

In changing the treatment of R\&D in National Accounts, the 2008 SNA created a need to establish robust and reliable estimates of R\&D output (including non-market R\&D and market producers' own-account R\&D), GFCF, imports, and exports in an economy. Due to the sum-of-costs approach adopted it was quite natural to turn to the consistent, reliable, and robust FM expenditure data existing in many countries. This use is a notable achievement for FM R\&D statistics and has significantly broadened the customer base and ultimately the audience for FM data. However, while National Accounts R\&D estimates draw heavily upon Frascati data, R\&D output and GFCF are fundamentally different concepts from Gross Domestic Expenditure on R\&D (GERD) and the many differences between FM and SNA R\&D statistics should be understood by practitioners and highlighted to users in an appropriate way. The most notable differences relate to the way capital inputs used for R\&D are accounted for and the recording of $R \& D$ undertaken in the course of developing software as software production in the National Accounts. This latter difference suggests a continuing role for "R\&D satellite accounts" in providing a complementary view focussed on $R \& D$ production.

FM 2015 answers many of the challenges laid out in the IPP Handbook (OECD, 2010). The changes, once implemented in statistical collection, can be used to improve the robustness of National Accounts R\&D statistics; more detailed expenditure breakdowns which permit more accurate accounting for expenditures on $R \& D$ inputs and the delineation of $R \& D$ related to software development, new information on the nature of funding provided for R\&D (i.e. exchange/transfer funds), and greater insight into Government Tax-Relief for R\&D and R\&D Globalisation are all of benefit.

It will be important for compilers of R\&D statistics to work together with National Accountants (and other stakeholders) to identify which of the new recommendations are of most use and their relative priority. Respondent burden, the availability and compatibility of information from alternative sources, and the specific features of the economy, industry, or units being covered should be considered and testing (cognitive, pilot etc.) of new questions is highly recommended in accordance with the new guidance on “Measuring R\&D: methodologies and procedures” (FM 2015, ch.6).

Successful implementation of the changes to the treatment to R\&D in the 2008 SNA relies on the production of robust sum-of-costs estimates of R\&D output. This requires bridging the differences between these two complicated statistical frameworks; a challenging task, but experience across various countries has shown good results from FM and SNA practitioners working together on data needs, challenges, limitations, etc. 


\section{REFERENCES}

Crawford, M., Lee, J. Jankowski, J. and Moris, F. (2014), "Measuring R\&D in the National Economic Accounting System, Bureau of Economic Analysis”, Washington DC.

http://www.bea.gov/scb/pdf/2014/11\%20November/1114_measuring_r\&d_in_the_national_econom ic_accounting_system.pdf.

European Commission (2011), European System of Accounts 2010, European Commission, Luxembourg. http://dx.doi.org/10.2785/16644

European Commission, International Monetary Fund, Organisation for Economic Co-operation and Development, United Nations, World Bank (2009), System of National Accounts 2008, United Nations, New York. https://unstats.un.org/unsd/nationalaccount/sna.asp

European Commission, International Monetary Fund, Organisation for Economic Co-operation and Development, United Nations, World Bank (1993) System of National Accounts 1993, United Nations, New York. https://unstats.un.org/unsd/nationalaccount/sna.asp

Ker, D. (2014), “Service Lives of R\&D assets”, Office for National Statistics, Newport, United Kingdom. http://www.iariw.org/papers/2014/KerPaper.pdf.

Moris, F., Jankowski, J., Boroush, M., Crawford, M, and Lee, J. (2015), “R\&D Recognised as Investment in U.S. GDP Statistics: GDP Increase Slightly Lowers R\&D-to-GDP Ratio”, National Science Foundation, Washington DC. www.nsf.gov/statistics/2015/nsf15315/.

OECD (2016), “Irish GDP up by 26.3\% in 2015?”, OECD, Paris. https://www.oecd.org/std/na/Irish-GDPup-in-2015-OECD.pdf

OECD (2015), Frascati Manual 2015: Guidelines for Collecting and Reporting Data on Research and Experimental Development, OECD Publishing, Paris. http://dx.doi.org/10.1787/9789264239012-en

OECD (2014), “OECD Estimates of R\&D Expenditure Growth in 2012”, OECD, Paris. http://www.oecd.org/sti/inno/Note_MSTI2013 2.pdf

OECD (2009), Handbook on Deriving Capital Measures of Intellectual Property Products, OECD Publishing, Paris. http://dx.doi.org/10.1787/9789264079205-en

OECD (2002), Frascati Manual: Proposed standard practice for surveys on Research and Experimental Development, OECD Publishing, Paris. http://dx.doi.org/10.1787/9789264199040-en

United Nations (2008a), Central Product Classification (CPC), Ver.2.1, United Nations, New York.

United Nations (2008b), International Standard Industrial Classification of All Economic Activities, Rev.4, United Nations, New York.

United Nations (n.d.) Classification of the Functions of Government, United Nations, New York.

Yorgason, D. (2007), “Treatment of International Research and Development as Investment: Issues and Estimates”, BEA/NSF R\&D Satellite Account Background Paper, Bureau of Economic Analysis, Washington DC. 


\section{NOTES}

1. The underlying roots of both frameworks date back to foundations laid in the 1930s.

2. Eurostat and the UNESCO Institute for Statistics participate in the NESTI and the revision of its statistical manuals.

3. The SNA covers all activities that result in the production of goods and services. Those produced for sale on the market are included, as are government activities in the areas of public administration, law and order, health, education and social services (and activities in often similar areas carried out by private non-profit organisations), even though their output is not sold on the market.

4. Key exceptions being the treatment of $R \& D$ services purchased by a unit specialised in R\&D (i.e. classified in ISIC industry 72) as intermediate consumption of their R\&D activity, and the exclusion of all R\&D relating to software development.

5. Because final consumption expenditures are already included in GDP, shifting expenditures from final consumption to investment alone would not impact GDP. However, classifying R\&D expenditures as investment increases the capital stock and so depreciation, which is included in the sum-of-costs valuation of non-market output. Note however that, by convention, no imputation is made for net operating surplus unlike in the market sector.

6. For example, Gross Value Added is the balancing item (residual) from contrasting a measure of an industry's Gross Output (=resource) against the value of the goods and services consumed in their production (Intermediate consumption) (=use).

7. This last requirement is related to the SNA definition of an asset which includes being transferrable.

8. when those transactions also satisfy SNA investment definitions

9. In accordance with the common economic principle that rational investors will not spend more on something (in this case R\&D) than they expect to make back in return and that, on average, they must therefore at least break even.

10. This may be quite volatile due to varying expenditure on high value items (such as buildings or industrial machinery) between periods.

11. When producers receive unrequited funds (from government or others) for the purchase of capital items these are treated "investment grants" in the National Accounts, these are not netted off the value of the capital items acquired. By contrast, they are netted off capital expenditures in the FM framework, as outlined in section " $R \& D$ costs".

12. The FM 2015 contains for the first time dedicated guidance on how to capture tax relief for R\&D with a dedicated new chapter (Ch. 13).

13. As the R\&D output of specialised commercial research laboratories or institutes is 'valued by receipts from sales, contracts, commissions, fees, etc. in the usual (SNA) way' -typically involving measurement through general business surveys of production and purchases - it should usually be clear which unit/industry/sector bought the R\&D. Conversely, where R\&D output has been estimated by sum- of-costs, the units/industries/sectors which end up owning and using the R\&D assets need to be identified. Units other than specialised commercial research laboratories may also sell R\&D on the market; this includes both non-market units (Government and NPISHs) and other market units which sell (or otherwise provide) R\&D alongside their main activities and/or own-account production of R\&D. 
14. including where the $R \& D$ is purchased from a specialist $R \& D$ performer (which would be classified in the Scientific R\&D industry) and cases where the purchaser happens to own the R\&D performing unit

15. For example, in the case of an outright patent sale, the acquisition of a pre-existing $\mathrm{R} \& \mathrm{D}$ asset should be matched by negative entry in the capital formation item of the seller, as it has disposed of an asset (unless the transaction was cross-border, in which case investment would increase). However, in the case of a nonexclusive licence to use a patent over a period of time, this does not require a negative entry as the seller retains rights on the use of the asset.

16. $\quad$ http://oe.cd/anberd

17. For this reason it may be desirable to continue the practice of compiling R\&D satellite accounts but with the new aim of presenting the "alternative" view where R\&D undertaken in the course of producing software is treated as creating $R \& D$ rather than software assets. 